\title{
PENGEMBANGAN VIDEO MEDIA PEMBELAJARAN MATA KULIAH PERANCANGAN JARINGAN KOMPUTER PROGRAM STUDI PENDIDIKAN INFORMATIKA UNIVERSITAS NEGERI JAKARTA
}

\author{
Nida Aulia Hasanah ${ }^{1}$, Hamidillah Ajie ${ }^{2}$, M. Ficky Duskarnaen ${ }^{3}$ \\ ${ }^{1}$ Mahasiswa Prodi PendidikanTeknik Informatika dan Komputer, Teknik Elektro, FT - UNJ \\ ${ }^{2,3}$ Dosen Prodi Pendidikan Teknik Informatika dan Komputer, Teknik Elektro, FT - UNJ \\ 1nidaulia02@gmail.com, ${ }^{2}$ hamidillah@unj.ac.id, ${ }^{3}$ duskarnaen@unj.ac.id
}

\begin{abstract}
Abstrak
Penelitian dilakukan dengan tujuan mengembangkan video media pembelajaran pada Mata Kuliah Perancangan Jaringan Komputer di Universitas Negeri Jakarta. Video media pembelajaran dibuat untuk memudahkan kegiatan belajar mengajar bagi dosen dan mahasiswa. Video media pembelajaran ini menggunakan video motion graphic sehingga menjadi video yang menarik. Penelitian dilakukan di Program Studi Pendidikan Informatika Universitas Negeri Jakarta dari bulan September 2018 sampai Desember 2018. Metode penelitian yang digunakan dalam penelitian ini adalah metode penelitian dan pengembangan (Research \& Development). Secara keseluruhan terdapat 3 tahap utama pada proses penelitian dan pengembangan ini, yakni (1) penelitian awal; (2) pengembangan produk; dan (3) pengujian serta revisi produk. Penelitian awal dilakukan guna mengidentifikasi permasalahan dan mencari solusi dalam menyelesaikan permasalahan tersebut. Proses pengujian produk dilakukan dengan ahli media, ahli materi dan mahasiswa sebagai pengguna. Proses pengumpulan data dilakukan dengan memanfaatkan kuesioner yang kemudian dianalisis dengan teknik deskriptif kuantitatif. Berdasarkan penelitian yang telah dilakukan, hasil pengujian oleh ahli materi menunjukkan bahwa produk mendapat nilai $90,76 \%$, hasil pengujian oleh ahli media mendapat nilai 85,71\%, pada uji coba kelompok kecil mendapat nilai $84 \%$ dan uji coba kelompok besar mendapat nilai 86,17\%. Berdasarkan hasil pengujian produk, video media pembelajaran yang telah dikembangkan dapat dinyatakan layak untuk digunakan pada Program Studi Pendidikan Informatika, Jurusan Teknik Elektro Universitas Negeri Jakarta.
\end{abstract}

Kata kunci : Video, Media Pembelajaran, Perancangan Jaringan Komputer

\section{Pendahuluan}

Kemajuan teknologi informasi kini berkembang sangat pesat secara global, mau tidak mau kita harus mengikutinya jika kita tidak ingin menjadi orang yang tertinggal informasi. Pemanfaatan teknologi informasi sudah menjadi kebutuhan utama di kalangan masyarakat. Kalangan akademis merupakan salah satu pihak yang mendapat keuntungan dari perkembangan kemajuan teknologi informasi.

Salah satu contoh kemajuan teknologi informasi yang berkembang saat ini adalah Internet. Menurut Supriyanto (2008: 60) Internet merupakan singkatan dari Interconnection Networking. Internet berasal dari bahasa latin "inter" yang berarti antara. Internet berarti jaringan antara atau penghubung, sehingga kesimpulan dari definisi Internet ialah merupakan hubungan antara berbagai jenis Internet dan jaringan di dunia yang berbeda sistem operasi maupun aplikasinya dimana hubungan tersebut memanfaatkan kemajuan komunikasi (telepon dan satelit) yang menggunakan Internet standar dalam berkomunikasi yaitu Internet TCP/IP (Transmission Control/Internet Protocol).

IP atau Internet Protokol adalah deretan angka biner antara 32 bit sampai 128 bit yang dipakai untuk setiap komputer host dalam jaringan internet. IP Address merupakan sebuah alamat pada komputer yang memungkinkan satu komputer dengan komputer lain memiliki satu tujuan pasti tanpa tertukar dengan komputer lain. Penjelasan tentang IP Address terdapat pada materi Penomoran IP dalam mata kuliah Jaringan Komputer yang akan berpengaruh pada mata kuliah Perancangan Jaringan Komputer.

Penomoran IP ini digunakan untuk menghitung bilangan biner dalam menentukan IP Address komputer, sehingga dapat dikatakan bahwa penomoran IP berperan penting dalam mata kuliah Jaringan Komputer maupun Perancangan Jaringan Komputer.

Ketika mahasiswa yang akan mengambil mata kuliah Perancangan Jaringan Komputer namun belum menguasai materi penomoran IP, maka hal ini akan 
berpengaruh pada materi selanjutnya. Namun kenyataannya masih ada dosen pengampu mata kuliah Jaringan Komputer yang belum menjelaskan perhitungan penomoran IP. Sehingga dosen pengampu mata kuliah Perancangan Jaringan Komputer harus mengulangi materi penomoran IP ini dari dasar yang seharusnya telah dipelajari pada mata kuliah Jaringan Komputer. Hal tersebut menghambat kegiatan belajar mengajar dikarenakan dosen pengampu harus mengulangi materi yang seharusnya telah dipelajari pada mata kuliah Jaringan Komputer.

Belum adanya media pembelajaran yang dapat dipelajari di luar kelas tentang materi Penomoran IP ini juga menjadi salah satu masalah yang dihadapi oleh dosen. Apabila terdapat media pembelajaran yang dapat dipelajari di luar kelas tentang materi ini, maka keterlambatan pengetahuan mahasiswa tentang materi ini dapat teratasi.

Berdasarkan latar belakang masalah diatas, masalah yang dapat diidentifikasi bahwa Mahasiswa belum mengerti materi dasar Penomoran IP dan belum adanya media pembelajaran berbasis video yang menjelaskan tentang materi Penomoran IP pada mata kuliah Perancangan Jaringan Komputer di lingkungan Program Studi Pendidikan Informatika Universitas Negeri Jakarta.

Pembuatan video media pembelajaran hanya berfokus pada materi pembelajaran Penomoran IP dalam Mata Kuliah Perancangan Jaringan Komputer. Video pembelajaran berupa kombinasi dari video animasi motion graphic. Video diimplementasikan untuk Mata Kuliah Perancangan Jaringan Komputer pada Program Studi Pendidikan Informatika di Universitas Negeri Jakarta.

\section{Dasar Teori}

Menurut Binanto (2010: 179) Video adalah teknologi pemrosesan sinyal elektronik yang mewakilkan gambar bergerak. Aplikasi umum dari teknologi video adalah televisi. Video itu sendiri juga dapat digunakan dalam aplikasi teknik, keilmuan, produksi, dan keamanan. Saat ini ada dua kategori video, yaitu video analog dan video digital.

Video analog mengodekan informasi gambar dengan memvariasikan voltase dan frekuensi dari sinyal. Seluruh sistem sebelum video digital dapat dikategorikan sebagai video analog.

Menurut Binanto (2010: 180) Video digital dapat disebut array 3 dimensi dari piksel berwarna. Dua dimensi melayani arah spasial dari gambar bergerak (horizontal dan vertikal) dan satu dimensi lainnya akan mempresentasikan domain waktu.

Arsitektur video digital tersusun atas sebuah format untuk mengodekan dan memainkan kembali video dengan komputer dan menyertakan pemutar (player) yang mengenali dan membuka file yang dibuat untuk format tersebut. Contoh arsitektur video digital diantaranya adalah Apple QuickTime,
Microsoft Windows Media Format dan Real Network RealMedia. Format video yang terkait dengan arsitektur tersebut adalah QuickTime movie (.mov), Audio Video Interleaved (.avi), dan RealMedia (.rm). Beberapa pemutar dapat mengenali dan memainkan lebih dari satu format file video. Video digital sebenarnya terdiri dari serangkaian gambar digital yang ditampilkan dengan cepat pada kecepatan yang konstan. Dalam konteks video, gambar ini disebut frame. Satuan untuk menghitung frame rata-rata yang ditampilkan disebut frame per second (fps). Setiap frame merupakan gambar digital yang terdiri dari raster piksel.

Menurut Arsyad (2011: 49) video merupakan gambar-gambar dalam frame, di mana frame demi frame diproyeksikan melalui lensa proyektor secara mekanis sehingga pada layar terlihat gambar hidup.

Dari pengertian di atas dapat disimpulkan, bahwa video merupakan salah satu jenis media audiovisual yang dapat menggambarkan suatu objek yang bergerak bersama-sama dengan suara alamiah atau suara yang sesuai. Kemampuan video melukiskan gambar hidup dan suara memberikan daya tarik tersendiri. Video dapat menyajikan informasi, memaparkan proses, menjelaskan konsep-konsep yang rumit, mengajarkan keterampilan, menyingkat atau memperpanjang waktu, dan mempengaruhi sikap.

Salah satu bentuk dari media audio visual adalah video pembelajaran. Video merupakan gambar gerak yang disertai suara yang membentuk satu kesatuan yang dirangkai menjadi sebuah alur, dengan pesanpesan di dalamnya untuk ketercapaian tujuan pembelajaran yang disimpan dengan proses penyimpanan pada media pita atau disk.

Media video adalah segala sesuatu yang menyangkut bahan (software) dan perangkat keras/alat (hardware), yaitu sesuatu benda yang dapat dilihat, didengar, atau diraba dengan pancaindera, penekanan media video pembelajaran terdapat pada visual dan audio yang dapat digunakan untuk meyampaikan isi materi ajar dari sumber belajar ke pembelajar (individu atau kelompok), yang dapat merangsang pikiran, perasaan, perhatian, minat pembelajar, dapat menangkap, memproses, dan menyusun kembali informasi visual atau verbal sedemikian rupa sehingga proses belajar (di dalam/di luar kelas) menjadi lebih efektif.

Sebagai media audio visual dengan memiliki unsur gerakan dan suara, video dapat digunakan sebagi alat bantu mengajar pada berbagai mata pelajaran. Benda-benda yang terlalu kecil, terlalu besar dan berbahaya atau bahkan tidak dapat dikunjungi oleh peserta didik karena lokasinya yang jauh, dapat dihadirkan melalui media video pembelajaran.

\section{Metodologi}


Metode ini dikembangkan dengan tujuan untuk mempermudah dan memperjelas proses pada saat pembuatan video sehingga alur cerita yang berupa naskah dapat tertata dengan baik dan tersampaikan kepada audience dalam bentuk visual yang menarik namun tetap mengandung informasi yang akan disampaikan.

Maka penelitian ini dilakukan dengan jenis penelitian Research and Development. Metode ini dirancang untuk mengembangkan suatu produk baru dan atau menyempurnakan produk yang telah ada dengan langkah-langkah yang dapat dipertanggung jawabkan. Langkah - langkah Penelitian Pengembangan ini meliputi :

1. Hasil observasi yang diperoleh dalam tahap ini kemudian dikumpulkan dan disusun menjadi data awal dari masalah yang ada dan nantinya akan ditindak lanjuti untuk dipecahkan. Dan Pengumpulan data untuk kebutuhan pengembangan video media pembelajaran perancangan jarinan komputer ini. Dimulai dengan memperoleh analisis data lapangan hingga pengumpulan data di Program Studi Pendidikan Informatika Universitas Negeri Jakarta.

2. Mengolah dan mulai membuat perencanaan untuk membangun media dengan membuat storyline dan storyboard menggunakan data yang telah dikumpulkan.

3. Melakukan penataan tampilan dan juga mendesain media pembelajaran

4. Melakukan uji coba media agar media dapat berjalan sesuai dengan apa yang dikehendaki.

5. Validasi video media pembelajaran perancangan jarinan komputer yang dihasilkan.

6. Analisis terhadap kelayakan media pembelajaran yang dihasilkan.

7. Perbaikan dan validasi media pembelajaran sesuai dengan masukan ahli media dan ahli materi.

8. Video media pembelajaran perancangan jarinan komputer pada materi penomoran IP dinyatakan layak dan efektif, sehingga dapat diterapkan sebagai salah satu sumber belajar mata kuliah perancangan jaringan komputer.

Secara keseluruhan proses pengembangan media pembelajaran selengkapnya dapat dilihat pada bagan seperti berikut :

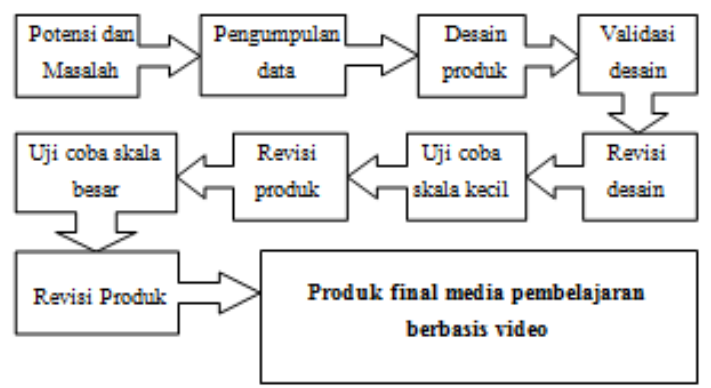

\section{Gambar 1. Langkah - langkah Penggunaan \\ Metode Research and Development (R\&D) modifikasi dari Sugiyono}

Pengumpulan data dapat digunakan sebagai bahan untuk perancangan produk yang diharapkan dapat mengatasi masalah tersebut.

Desain Produk, untuk membuat suatu video profil, rancangan produk dibuat dengan berdasarkan masalah maupun informasi yang telah didapat sebelumnya. Desain produk yang diperlukan untuk pengembangan video media pembelajaran, yaitu storyline, storyboard dan desain video media pembelajaran.

Validasi desain merupakan proses penilaian apakah suatu produk yang dihasilkan akan lebih efektif dari sebelumnya atau tidak. Sebelum diimplementasikan tentunya video media pembelajaran ini perlu dievaluasi agar diketahui kelemahan dan kelebihan serta memperoleh masukan awal. Data yang diambil merupakan data hasil validasi ahli materi, ahli media, dan responden. Instrumen yang digunakan berupa lembar validasi ahli dan kuesioner responden.

Teknik analisis data yang digunakan dalam penelitian ini yaitu teknik analisis deskriptif kuantitatif. Rumus yang digunakan dapat dilihat pada Persamaan.

$P=\frac{f}{n} \times 100 \%$

Keterangan:

$P P=$ Presentase

$n n=$ Jumlah Skor Ideal

$f f=$ Frekuensi dari setiap jawaban angket

Kriteria untuk menilai ketercapaian aspek dan kelayakan produk yang dihasilkan disajikan dalam tabel 1 berikut:

Tabel 1. Pengelompokan Kategori Kualitas Berdasarkan Presentase

\begin{tabular}{|c|c|}
\hline Prensentase Pencapaian & Interpretasi \\
\hline $81 \%-100 \%$ & Sangat Sesuai \\
\hline $61 \%-80 \%$ & Sesuai \\
\hline $51 \%-75 \%$ & Cukup Sesuai \\
\hline $26 \%-50 \%$ & Kurang Sesuai \\
\hline $0 \%-25 \%$ & Tidak Sesuai \\
\hline
\end{tabular}

Sumber: Suharsimi Arikunto (2010:44)

Revisi desain dilakukan jika hasil evaluasi dan saran dari validator memiliki kekurangan atau masukan untuk pengembangan produk. Jika hasil 
evaluasi memiliki kekurangan hendaknya merevisi kembali hingga mencapai perhitungan presentase kelayakan produk.

Uji coba termasuk dalam rangkaian evaluasi. Tahapan ini dilakukan untuk uji coba skala kecil dengan responden adalah siswa baru berjumlah 5 orang. Uji coba skala besar dilakukan dengan responden adalah siswa baru berjumlah 20 orang.

Revisi produk tahapan akhir apabila dalam pemakaian produk pada kelompok yang lebih luas jika terdapat kekuarangan, maka pembuat produk harus mengevaluasi kembali bagaimana kinerja produk. Dari hasil evaluasi produk tersebut dapat dijadikan untuk penyempurnaan dan pembuatan produk baru lagi.

Tahap ini merupakan tahap akhir dan siap untuk digunakan sebagai media informasi dari video media pembelajaran mata kuliah Perancangan Jaringan Komputer.

\section{Hasil dan Pembahasan}

Hasil pengembangan produk adalah tahap hasil dari produk yang sudah diteliti dan dikembangkan. Disini pengembang mengembangkan sebuah media pembelajaran berbasis video yang berjudul Pengembangan Video Media Pembelajaran Mata Kuliah Perancangan Jaringan Komputer Program Studi Pendidikan Informatika Universitas Negeri Jakarta. Video ini dikembangkan dengan teknik motion graphic yang berisikan gambar, logo, typografi serta musik. Pengembangan video ini bertujuan untuk memudahkan mahasiswa dalam mempelajari materi penomoran IP. Penelitian dalam pengembangan produk video media pembelajaran ini dilakukan di Universitas Negeri Jakarta dengan Progam Studi Pendidikan Informatika.

Berikut merupakan kebutuhan perangkat lunak serta perangkat keras serta komponen - komponen pendukung lainnya yang dibutuhkan untuk membuat dan mengembangkan video media pembelajaran:

1. Perangkat keras yang digunakan pada Notebook ASUS S200E-CT158H dalam pengembangan dan pembuatan video motion graphic ini adalah :

Processor : Intel Core i3-3217U $1.6 \mathrm{GHz}$

Hard Drive : 500GB HDD

System Operation : Windows 8.1 64-Bit.

Memory : 4 GB

Monitor : 11.6"

2. Dalam pengembangan dan pembuatan video media pembelajaran ini peneliti menggunakan beberapa perangkat lunak, yaitu :
a. Adobe Premiere Pro CC 2015
b. Adobe After Effect CC 2015
c. Adobe Photosop CC 2015
d. Adobe Audition CC 2015

3. Dalam pengembangan video motion graphic ini, peneliti juga mengumpulkan komponenkomponen pendukung lainnya yang juga berpengaruh dalam pembuatan video ini, diantaranya adalah :

a. Video tutorial pembuatan motion graphic yang didapat dari http://www.youtube.com

b. Referensi gambar-gambar ilustrasi yang peneliti dapatkan dari www.google.com dan www. freepik.com.

Produk yang telah dibuat kemudian dilakukan pengujian oleh para ahli. Baik oleh ahli materi atau ahli media. Pengujian ini bertujuan untuk mengetahui apakah media sudah layak atau masih perlu dilakukan perbaikan sebelum ditampilkan kepada responden.

Persentase kelayakan produk berdasarkan uji dari ahli materi :

Presentase $=\frac{5959}{6565} \times 100 \% \frac{5}{5} \times 100 \% \frac{5}{5} \times 100 \%=$ $\mathbf{9 0 , 7 \%}$

Berdasarkan garis kontinum interpretasi kategori kualias berdasarkan skor. Dapat disimpulkan bahwa video media pembelajaran ini mendapat presentase kelayakan 90,7\%. Skor tersebut terdapat pada interval "sangat baik" sesuai dengan Tabel 1 Persentase Skala Rating.

Persentase kelayakan produk berdasarkan uji dari ahli materi :

Presentase $=\frac{6060}{7070} \times 100 \% \frac{5}{5} \times 100 \% \frac{5}{5} \times 100 \%=$ $85,7 \%$

Berdasarkan garis kontinum interpretasi kategori kualias berdasarkan skor. Dapat disimpulkan bahwa video media pembelajaran ini mendapat presentase kelayakan $85,7 \%$. Skor tersebut terdapat pada interval "sangat baik" sesuai dengan Tabel 1 Persentase Skala Rating.

\section{Presentase Responden Kecil}

$$
=\frac{294}{350} \times 100 \% \frac{294}{350} \times 100 \%=84 \%
$$

Dapat disimpulkan bahwa produk ini mendapat presentase kelayakan $\mathbf{8 4 \%}$. Skor tersebut terdapat pada interval "sangat sesuai" sesuai dengan tabel 1 pengelompokan kategori kualitas berdasarkan presentase.

Presentase Responden Besar

$=\frac{1508}{1750} \times 100 \frac{1508}{1750} \times 100=86,2 \%$

Berdasarkan garis kontinum interpretasi kategori kualias berdasarkan skor, dapat disimpulkan bahwa produk ini mendapat presentase kelayakan 
$86,2 \%$. Skor tersebut terdapat pada interval "sangat sesuai" sesuai dengan tabel 1 pengelompokkan kategori kualitas berdasarkan presentase.

\section{Kesimpulan}

Penelitian ini menghasilkan video media pembelajaran Perancangan Jaringan Komputer pada materi dasar Penomoran IP di Program Studi Pendidikan Informatika Universitas Negeri Jakarta. Berdasarkan uji kelayakan dan keefektivitas penggunaan dalam penelitian ini yang terdiri dari : 1) uji ahli materi; 2) uji ahli media; 3) uji kelompok kecil; 4) uji kelompok besar, maka hasil yang diperoleh adalah sebagai berikut :

1. Video media pembelajaran ini mendapatkan kelayakan sangat baik pada saat uji ahli media, materi serta responden baik dalam kelompok besar maupun kecil.

2. Menurut hasil perhitungan data responden, pada uji kelompok kecil terhadap 5 mahasiswa, diperoleh data bahwa persentase kelayakan produk skor secara keseluruhan $84 \%$.

3. Menurut hasil perhitungan data responden, pada uji kelompok besar terhadap 25 mahasiswa, diperoleh data bahwa persentase kelayakan produk skor secara keseluruhan $86,2 \%$

\section{Daftar Pustaka:}

Anam, Khoirul. (2015). Pembelajaran Berbasis Inkuiri : Metode dan Aplikasi. Yogyakarta: Pustaka Pelajar (IKAPI)

Arsyad, Azhar. (2013). Media Pembelajaran. Jakarta: PT. RajaGrafindo Persada

Binanto, Iwan. (2010). Multimedia Digital : Dasar Teori dan Pengembangannya. Yogyakarta: Andi.

Effendi, Empy \& Zhuang, Hartono. (2005). Elearning : Konsep dan Aplikasi. Yogyakarta: Andi.

Jakarta: Fakultas Teknik, Universitas Negeri Jakarta. Hamalik, Oemar. (1989). Media Pendidikan. Bandung : Citra Aditya.

Hamzah \& Lamatenggo, Nina. (2011). Teknologi Komunikasi \& Informasi Pembelajaran. Jakarta: PT. Bumi Aksara.

Munir. (2012). Pembelajaran Jarak Jauh. Bandung: Alfabeta.

Sadiman, Arief., dkk. (2012). Media Pendidikan. Jakarta: PT. RajaGrafindo Persada.

Sugiyono. (2015). Metode Penelitian dan Pengembangan (Research and Development/R\&D. Bandung: Alfabeta.

Suharsimi, Arikunto. (2006). Prosedur Penelitian Suatu Pendekatan Praktik, Jakarta: Rineka Cipta.

Sukiman. (2012). Pengembangan Media Pembelajaran, Yogyakarta: PT. Pustaka Insan Madani, Anggota IKAPI.
Supriyatno, Wahyu dan Muhsin, Ahmad. (2008). Teknologi Informasi Perpustakaan: Strategi Perencanaan Perpustakaan Digital. Yogyakarta: Kanisius.

Susilana, Rudy \& Riyana, Cepi. (2009). Media Pembelajaran:Hakikat,Pengembangan,Pemanfa atan,dan Penilaian. Bandung: CV Wacana Prima.

Usman, Basyiruddin \& Asnawir. (2002). Media Pembelajaran. Jakarta: Ciputat Pers. 